\title{
Semaphorin 3A Is Required for Guidance of Olfactory Axons in Mice
}

\author{
Gerald A. Schwarting, ${ }^{1,2}$ Christine Kostek, ${ }^{1}$ Naira Ahmad, ${ }^{1}$ Christian Dibble, ${ }^{1}$ Laurent Pays, ${ }^{1}$ and \\ Andreas W. Püschel ${ }^{3}$ \\ ${ }^{1}$ The Shriver Center, Waltham, Massachusetts 02452, ${ }^{2}$ Department of Cell Biology, University of Massachusetts Medical \\ School, Worcester, Massachusetts 01655, and 3Molecular Genetics Laboratory, Department of Neurochemistry, Max- \\ Planck-Institut for Brain Research, D-60528 Frankfurt, Germany
}

\begin{abstract}
Semaphorin 3A (Sema3A) is a membrane-associated secreted protein that has chemorepulsive properties for neuropilin-1 (npn-1)expressing axons. Although mice lacking the Sema3A protein display skeletal abnormalities and heart defects, most axonal projections in the CNS develop normally. We show here that Sema3A is expressed in the lamina propria surrounding the olfactory epithelium (OE) and by ensheathing cells in the nerve layer of the ventral olfactory bulb (OB) throughout development. Subsets of sensory neurons expressing npn-1 are distributed throughout the OE and extend fibers to the developing OB. In wild-type mice, npn-1-positive $\left(\mathrm{npn}-1^{+}\right)$axons extend to lateral targets in the rostral $\mathrm{OB}$ and medial targets in the caudal OB, avoiding regions expressing Sema3A. In Sema3A homozygous mutant mice, many npn- $1^{+}$axons are misrouted into and through the
\end{abstract}

Patterning in the olfactory system is characterized by convergence of axons from broad regions of the olfactory epithelium (OE) to a small number of glomeruli in the olfactory bulb (OB). Although four circumscribed zones in the $\mathrm{OE}$ can be identified by their expression of odorant receptors, the corresponding OB zones have been more difficult to identify (Wang et al., 1998; Lin and Ngai, 1999). Other than the odorant receptors themselves, few molecules have been identified that definitively play a role in guidance of olfactory neurons. OCAM is the only neuronal protein known to be expressed in a pattern corresponding to the receptor-defined zones (for review, see Mori et al., 1999). OCAM-positive $\left(\mathrm{OCAM}^{+}\right)$cell bodies are confined to the ventral and lateral OE, and $\mathrm{OCAM}^{+}$axons preferentially terminate in the ventral and lateral OB (Yoshihara et al., 1997). Other indications of restricted patterning of sensory axons in the main $\mathrm{OB}$ include a widely distributed neuronal subset expressing lactosamine-containing glycans (LCG) that converge on the ventromedial OB (St. John and Key, 1999, unpublished observation) (J. E. Crandall, C. Dibble, D. Butler, L. Pays, N. Ahmad, C. Kostek, and A. W. Püschel, unpublished observations) and neuropilin-1-positive (npn-1 ${ }^{+}$) axons that terminate in the medial and lateral glomeruli but not in dorsal or ventral targets (Pasterkamp et al., 1998). These latter studies suggest that receptor-defined zonal boundaries may represent only one of several compartmental restrictions for patterning of sensory inputs to the olfactory bulb.

Semaphorins constitute a large family of proteins characterized by the presence of a highly conserved semaphorin domain and have been implicated in axon guidance from flies to vertebrates. The most studied vertebrate family member is Sema3A, originally named collapsin-1 in chick, Sema III in humans, and SemD in

\footnotetext{
Received April 14, 2000; revised June 26, 2000; accepted Aug. 4, 2000.

This work was supported by National Institutes of Health Grant DC00953 (to G.S.) and a grant from the Deutsche Forschungsgemeinschaft (to A.W.P.). We thank Oded Behar for the breeding pairs of heterozygote Sema3A mutant mice. We thank Kensaku Mori for OCAM antibodies.

Correspondence should be addressed to Gerald A. Schwarting, The Shriver Center, 200 Trapelo Road, Waltham, MA 02452. E-mail: gschwarting@shriver.org. Copyright (C) 2000 Society for Neuroscience 0270-6474/00/207691-07\$15.00/0
}

ventral nerve layer, beginning as early as embryonic day 13 and continuing at least until birth. At postnatal day $0, \mathrm{npn}-1^{+}$glomeruli are atypically located in the ventral $\mathrm{OB}$ of Sema3 $\mathrm{A}^{-/-}$ mice, indicating that aberrant axon trajectories are not corrected during development and that connections are made in inappropriate target regions. In addition, subsets of $\mathrm{OCAM}^{+}$axons that normally project to the ventrolateral $\mathrm{OB}$ and some lactosaminecontaining glycan ${ }^{+}$axons that normally target the ventral $\mathrm{OB}$ are also misrouted in Sema3A mutants. These observations indicate that Sema3A expression by ensheathing cells plays an important role in guiding olfactory axons into specific compartments of the $\mathrm{OB}$.

Key words: Sema3A; neuropilin-1; ensheathing cells; axon guidance; olfactory; pattern formation rodents (Luo et al., 1993; Püschel et al., 1995; Kitsukawa et al., 1997; Kolodkin et al., 1997). Olfactory neurons and their axons express npn-1, which serves as the ligand-binding subunit in the Sema3A receptor (Kawakami et al., 1995; Takahashi et al., 1999; Tamagnone et al., 1999; Rohm et al., 2000). In chick embryos, Sema3A is expressed in the developing telencephalon and prevents premature entry of olfactory axons (Kobayashi et al., 1997). Sema3A is also widely expressed in the developing rat olfactory system in which its expression at the periphery of the telencephalic vesicle may prevent penetration of initial olfactory fibers. It is also thought that laminar Sema3A expression in OB neurons prevents axon growth beyond the glomerular layer (Pasterkamp et al., 1998).

In addition to its previously described expression in mitral and tufted cells in the OB and in mesenchyme in the cribriform plate, we show here that Sema3A is differentially expressed by $\mathrm{p} 75^{+}$ ensheathing cells in the nerve layer of the OB. Npn- $1^{+}$olfactory axons extend into glomeruli in the medial and lateral regions of the $\mathrm{OB}$, complementary to the pattern of Sema3A expression. In mice lacking Sema3A, however, npn- $1^{+}$axons are misrouted throughout the embryonic nerve layer and terminate inappropriately in ventral glomeruli of neonatal mutant mice.

\section{MATERIALS AND METHODS}

Animals and tissue preparation. Timed pregnant [plug date, embryonic day 0 (E0)] and postnatal C57BL/6 mice, or semaIII (Sema3A) mutant mice (Behar et al., 1996) were deeply anesthetized with a mixture of ketamine $(50 \mathrm{mg} / \mathrm{kg}$, b.w.) and xylazine $(10 \mathrm{mg} / \mathrm{kg}$, b.w.), and individual embryos or postnatal pups were perfused intracardially using $4 \%$ paraformaldehyde in $0.1 \mathrm{~m}$ phosphate buffer, $\mathrm{pH} 7.4$, or with periodate-lysine-paraformaldehyde in $0.05 \mathrm{M}$ phosphate buffer $(2 \%$ paraformaldehyde, $0.075 \mathrm{M} \mathrm{L}$-lysine, and $0.214 \%$ sodium metaperiodate) in accord with the Institutional Animal Care and Use Committee at the Shriver Center. The heads were post-fixed overnight and then cryopreserved in PBS containing $30 \%$ su-

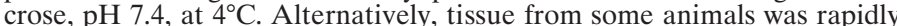
frozen in isopentane at $-70^{\circ} \mathrm{C}$, sectioned with a cryostat, and thawmounted onto coated slides (SuperFrost; Fisher Scientific, Houston, TX). Sema3 $\mathrm{A}^{+1+}$, Sema3 $\mathrm{A}^{+1-}$, and Sema3 $\mathrm{A}^{-1-}$ mice were produced by mating Sema3A ${ }^{+1-}$ animals. Genotypes of embryos were analyzed by PCR of tail DNA. Normal litter sizes were obtained, but all homozygous mutants died on postnatal day 0 (P0) or P1. To control for timing variations, comparisons of wild-type and mutant animals are from within individual litters. 

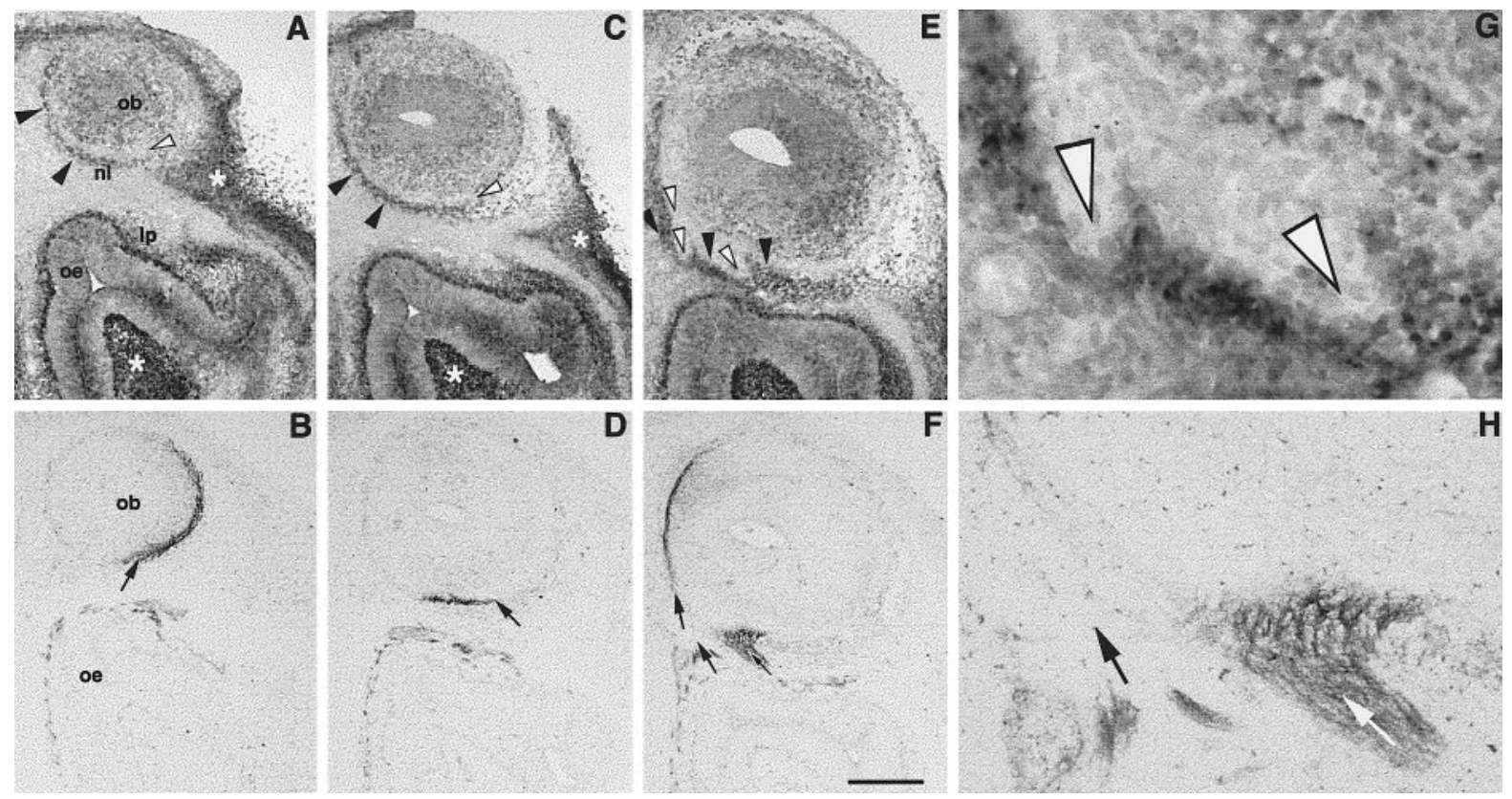

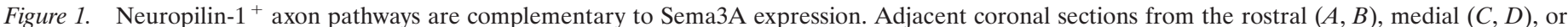

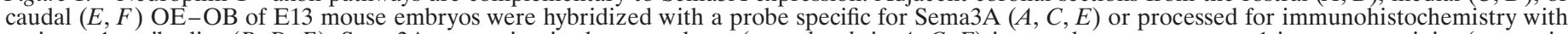

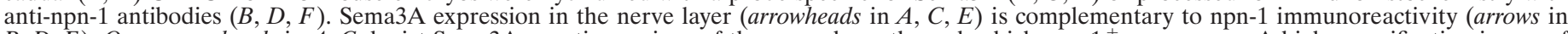

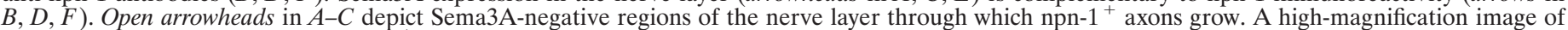

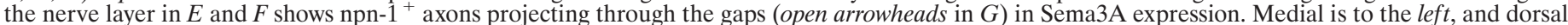

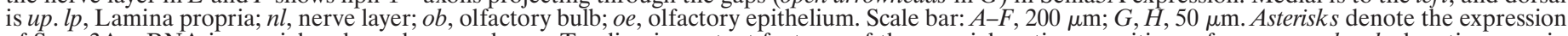

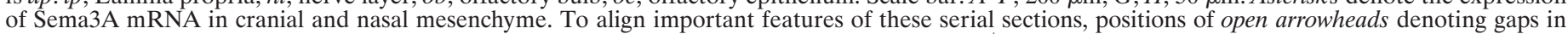
Sema3A expression in $A, C, E$, and $G$ are matched with the positions of arrows marking npn- $1^{+}$axon bundles in $B, D, F$, and $H$.

Antibodies. The mouse monoclonal antibody 1B2 (IgM) (Young et al., 1981), against the LCG epitope was obtained from The American Type Culture Collection (Rockville, MD). We have identified previously a single glycolipid present in the olfactory system that is highly immunoreactive with the 1B2 antibody (Schwarting and Crandall, 1991). Neuropilin-1 antibodies were obtained from Oncogene Sciences (Cambridge, MA). Polyclonal antibodies to OCAM were a gift from K. Mori (Brain Science Institute, Riken, Japan). Rabbit polyclonal antiserum (IgG) against anti-mouse p75 (the low-affinity nerve growth factor receptor) was purchased from Chemicon (Temecula, CA).

In situ hybridization. Digoxigenin (DIG)-labeled RNA probes for Sema3A (Püschel et al., 1995) were generated according to the methods described in the Boehringer Mannheim (Indianapolis, IN)Genius 4 kit. In situ hybridization was performed on coronal cryostat sections through the $\mathrm{OE}$ and OB of mice. Briefly, slides were treated with proteinase K (Boehringer Mannheim), treated with acetic anhydride in $0.1 \mathrm{M}$ triethanolamine for $10 \mathrm{~min}$, and then dehydrated through graded ethanol solutions. Hybridization was performed at $55-56^{\circ} \mathrm{C}$ for $15 \mathrm{hr}$. Slides were washed in SSC at $55^{\circ} \mathrm{C}$, followed by a formamide wash at $55^{\circ} \mathrm{C}$ and $\mathrm{SSC}$ washes at $37^{\circ} \mathrm{C}$. DIG-labeled RNA hybrids were reacted with alkaline phosphataseconjugated anti-DIG Fab antibodies (Boehringer Mannheim). Reaction product was visualized by incubating the sections with nitro-blue tetrazolium chloride and 5-bromo-4-chloro-3-indolylphosphate (Sigma, St. Louis, MO) overnight at room temperature for $15 \mathrm{hr}$.

Immunohistochemistry and immunofluorescence. Cryopreserved heads were rapidly frozen and sectioned at various thickness $(30-60 \mu \mathrm{m})$ with a sliding microtome in either the coronal or sagittal plane. Free-floating sections were incubated overnight at $4^{\circ} \mathrm{C}$ with primary antibody diluted in PBS containing $1 \%$ bovine serum albumin (BSA) (Sigma) and $0.2 \%$ Triton $\mathrm{X}-100$. Incubation with secondary antibody diluted in PBS containing $1 \%$ BSA was performed for $2 \mathrm{hr}$ at room temperature. For immunohistochemistry, biotinylated secondary antibodies (Jackson ImmunoResearch, West Grove, PA) were used in combination with avidin-biotin-horseradish peroxidase (Vectastain standard ABC kit; Vector Laboratories, Burlington, $\mathrm{CA}$ ) and visualized with a diaminobenzidine-nickel reaction. For immunofluorescence, FITC- or Cy3-conjugated secondary antibodies (Jackson ImmunoResearch) were used, or in some cases, biotinylated secondary antibodies were used in combination with $\mathrm{Cy} 3$-conjugated streptavidin.

Combined fluorescence in situ hybridization and immunocytochemistry. For both cell culture and cryosection experiments, we used a protocol for fluorescence double-labeling by in situ hybridization and immunocytochemistry (Wanner et al., 1997). The Sema3A digoxigenin-riboprobe was detected using a Tyramide Signal Amplification-Direct Cy3 kit (NEN, Boston, MA). Ensheathing cells were visualized using the antibody to p75 and FITC-conjugated donkey anti-rabbit IgG (Jackson ImmunoResearch) Minor adaptations were made concerning the hybridization buffer, which contained $10 \mathrm{~mm}$ Tris- $\mathrm{HCl}, \mathrm{pH} 7.5,300 \mathrm{~mm} \mathrm{NaCl}, 1 \mathrm{~mm}$ EDTA, 50\% deionized formamide, $10 \%$ dextran sulfate, and $1 \%$ blocking reagent (Roche Products, Hertforshire, UK).

\section{RESULTS}

\section{Sema3A and npn-1 expression during embryonic development}

Axons from the OE extend to the rostral end of the telencephalon at E11, and the OB begins to develop at E12. At this age, Sema3A is heavily expressed by non-neuronal cells along axon pathways between the $\mathrm{OE}$ and $\mathrm{OB}$, and npn- $1^{+}$axons have made contact with the $\mathrm{OB}$ in Sema3A-negative regions of the developing nerve layer (data not shown). At E13, Sema3A mRNA is expressed in the lamina propria surrounding the olfactory epithelium and in a sheet of cells in the nerve layer surrounding the olfactory bulb (Fig. 1). In a series of coronal sections, Sema3 $\mathrm{A}$ is expressed in the nerve layer medially and ventrally in the rostral $\mathrm{OB}$ (Fig. $1 A$ ) and central $\mathrm{OB}$ (Fig. $1 C$ ), but in the caudal OB (Fig. $1 E$ ) Sema3A expression in the ventral nerve layer is characterized by gaps in expression. This changing pattern of Sema3A expression in the nerve layer along the rostrocaudal axis continues throughout development. In rostral and central sections, Sema3A is also expressed by cranial mesenchymal cells, as described previously (Giger et al., 1996).

Npn-1 is expressed by sensory neurons scattered throughout the olfactory epithelium in rats, and npn- $1^{+}$axons terminate, depending on their rostrocaudal position, in medial and lateral glomeruli. In coronal sections through the E13 mouse OB, npn- ${ }^{+}$axons extend into the lateral nerve layer of the rostral OB (Fig. $1 B$ ). In the central OB (Fig. $1 D)$, npn- $1^{+}$axons track ventrally, but in the caudal OB (Fig. $1 F$ ), npn-1 ${ }^{+}$axons grow through the ventral nerve layer into the medial nerve layer. In each set of matched serial sections through the E13 OB, npn $-1^{+}$axons grow through the inner nerve layer, whereas Sema3 $\mathrm{A}^{+}$cells are in the outer nerve layer. Rostrally and centrally, Sema3A expression in the medial nerve layer directs npn- $1^{+}$axons laterally. Caudally, Sema3A expression in the ventral nerve layer forms channels through which npn- $1^{+}$ axons extend into the medial nerve layer. A higher magnification image of the caudal nerve layer (Fig. $1 G, H$ ) shows npn- $1^{+}$axon 


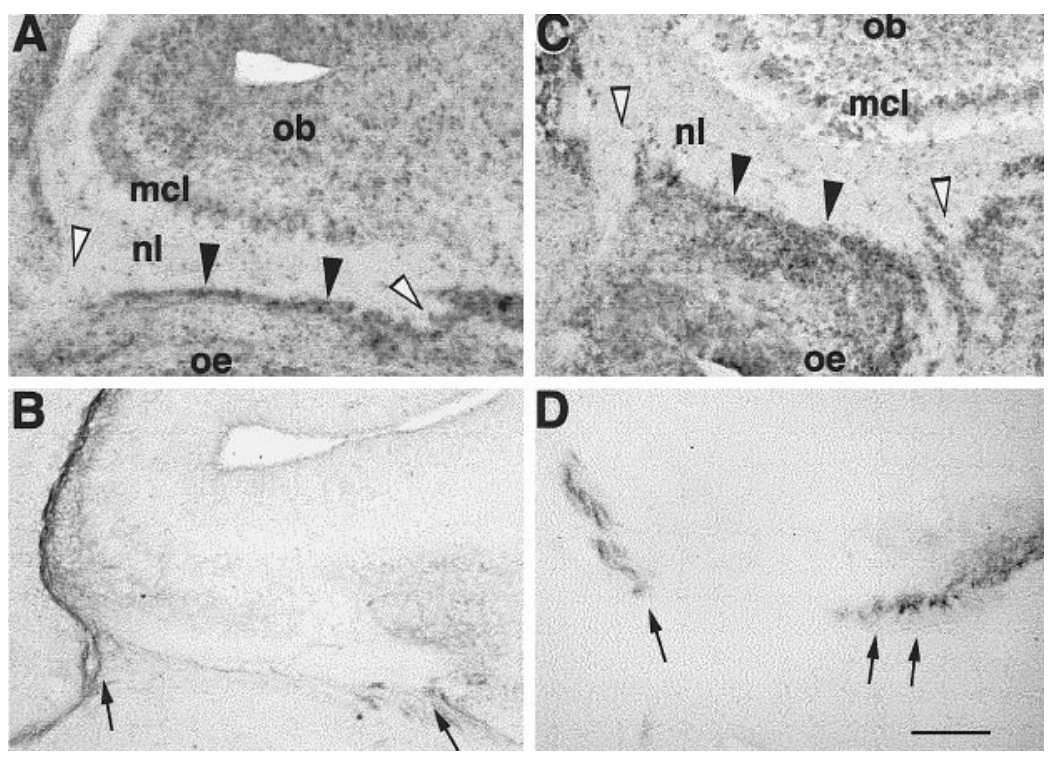

Figure 2. $\quad \mathrm{Npn}^{+} \mathrm{1}^{+}$axons avoid Sema3A expressed in the ventral OB. Adjacent sagittal $(A, B)$ or coronal sections $(C, D)$ from $\mathrm{E} 15$ mouse embryos were hybridized with a probe specific for Sema3A $(A, C)$ or processed for immunohistochemistry with anti-npn- 1 antibodies $(B, D)$. In the sagittal plane, rostral and caudal gaps in Sema3A expression (open arrowheads in $A$ ) flank a long row of Sema3 $\mathrm{A}^{+}$cells (arrowheads in $A$ ) in the outer nerve layer of the ventral $\mathrm{OB}$. In an adjacent section, npn- $1^{+}$axons (arrows in $B$ ) extend through the gaps in Sema3A expression to either rostrolateral or caudomedial regions of the nerve layer. In the coronal plane, gaps in Sema3A expression at the ventral midline of the $\mathrm{OB}$ and in the medial nerve layer (open arrowheads in $C$ ) surround a dense cluster of Sema3 $\mathrm{A}^{+}$ cells in the ventromedial nerve layer (arrowheads in $C$ ). Npn- $1^{+}$axons extend laterally or medially (arrows in $D$ ) through gaps in Sema3A expression. In $A$ and $B$, rostral is left, and dorsal is up. In $C$ and $D$, medial is left, and dorsal is $u p$. Scale bar, $100 \mu \mathrm{m}$. bundles growing through gaps in Sema3A expression, but npn-1 ${ }^{+}$ axon bundles do not overlap with Sema3 $\mathrm{A}^{+}$cells.

At E15, the pattern of Sema3A mRNA expression and the trajectories of npn- $1^{+}$axons are complementary. In a sagittal section through the E15 OB, Sema3A mRNA is found in the outer nerve layer in a block of cells distributed along the ventral surface of the OB (Fig. $2 A$ ), with small gaps near the rostral and caudal ends of the OB. In a serial section in Figure $2 A$, npn- $1^{+}$axons grow rostrally and caudally (Fig. $2 B$ ) in regions where Sema3A is absent. In a coronal section through the central OB, large gaps in Sema3A expression in the medial and ventral nerve layer (Fig. 2C) flank a region of heavy Sema3A expression in the ventromedial nerve layer. Npn- $1^{+}$axons enter the inner nerve layer through these gaps in Sema3A expression (Fig. 2D).

\section{Sema3A is expressed in the nerve layer of the ventral OB by $\mathrm{p}^{+} 5^{+}$ensheathing cells}

Sema3A is expressed by several cell types in the developing olfactory system, as demonstrated previously (Giger et al., 1996; Pasterkamp et al., 1998). Using double-label techniques, we examined the expression of Sema3A simultaneously with markers for ensheathing glial cells that populate the nerve layer (Gong and Shipley, 1996; Kafitz and Greer, 1998). A coronal section through the OE and OB of a E15 mouse was probed for the expression of Sema3A mRNA by in situ hybridization and also reacted with antibodies to p75, a marker for ensheathing cells. p75, the lowaffinity NGF receptor, is expressed by cells in the lamina propria and by cells in the outer nerve layer of the OB (Fig. $3 A$ ). Sema3A (Fig. $3 B$ ) is expressed by cells in the lamina propria, by mitral cells in the OB, and by cells in the outer nerve layer. Some p $75^{+}$ ensheathing cells in the nerve layer also express Sema3A (Fig. 3C). A higher magnification image of the nerve layer (Fig. $3 D$ ) shows that Sema3A mRNA and $\mathrm{p} 75^{+}$cell surface protein are coexpressed by ensheathing cells in the outer nerve layer.

\section{Npn-1 ${ }^{+}$axon trajectories are perturbed in Sema3A mutant mice}

The trajectories of npn- $1^{+}$axons were compared in mutant mice lacking Sema3A with their wild-type littermates at E13. Npn-1 ${ }^{+}$ axons grow laterally in the rostral OB (Fig. $4 A$ ), both medially and ventrolaterally in the central $\mathrm{OB}$ (Fig. $4 C$ ), and medially in the caudal OB (Fig. 4E). In mutant mice lacking Sema3A, npn- $1^{+}$ axons grow diffusely into the dorsolateral and ventrolateral nerve layer in the rostral OB (Fig. 4B). In the central and caudal regions of the $\mathrm{OB}, \mathrm{npn}-1^{+}$axons extend inappropriately into the ventral
OB (Fig. $4 D, F$ ). Although there are very few npn- $1^{+}$axons at this age, these results suggest that the majority of these axons grow into the OB despite the loss of Sema3A throughout the nasal mesenchyme. However, it is not possible at this stage to determine whether the abnormal growth of npn-1 fibers is attributable to defasciculation or to pathfinding defects.

\section{Npn-1 ${ }^{+}$axons are misrouted in Sema3A mutant mice at E15}

At E15, the number of npn- $1^{+}$axons growing into medial and lateral targets of wild-type mice increased significantly compared with $2 \mathrm{~d}$ earlier. In coronal sections $\sim 200 \mu \mathrm{m}$ from the rostral tip of the $\mathrm{OB}$ of wild-type mice, npn- $1^{+}$axons grow laterally (Fig. $5 A$ ), whereas in a matched section at the same position and at the same plane from a Sema3 $\mathrm{A}^{-1-}$ littermate (Fig. $5 B$ ), npn- $1^{+}$axons are detectable in most regions of the $\mathrm{OB}$. In coronal sections through the central OB (200 $\mu \mathrm{m}$ caudal to the sections in $A$ and $B), n p n-1^{+}$ axons preferentially grow laterally and to a lesser extent medially (Fig. 5C), but in matched sections from mutant mice (Fig. 5D), npn- $1^{+}$axon trajectories extend into the ventral and medial OB. A high-magnification image (Fig. $5 E, F$ ) of the ventral nerve layer in Figure 5, $C$ and $D$, respectively, shows that npn- $1^{+}$axons grow into and through the ventral nerve layer in mutant mice, an area in which few npn- $1^{+}$axons are able to penetrate in normal animals. In the caudal OB (100 $\mu \mathrm{m}$ caudal to the sections in $C$ and $D)$ of wild-type $(G)$ and mutant $(H)$ mice, little difference is seen between npn- $1^{+}$axon trajectories. There does not appear to be any evidence of defasciculation of mutant axon fascicles in the caudal $\mathrm{OB}$; in fact, they may be more tightly bundled than wild-type fascicles.

\section{Positions of npn-1 ${ }^{+}$glomeruli are perturbed in newborn Sema3A mutant mice}

The importance of Sema3A in olfactory development was further supported by a comparison of npn- $1^{+}, \mathrm{OCAM}^{+}$, and $\mathrm{LCG}^{+}$glomeruli in $\mathrm{P} 0$ wild-type and mutant mice. In coronal sections through the nerve layer of the rostral $\mathrm{OB}$, npn- ${ }^{+}$axons grow laterally in wild-type mice (Fig. 6A) but, as is the case in the embryo, are dispersed into all regions of the rostral OB in Sema3A mutant mice (Fig. $6 B$ ). In addition, small, faint npn- $1^{+}$protoglomeruli are visible in the rostrolateral $\mathrm{OB}$ of wild-type mice (Fig. $6 C$ ). In mutant mice, npn- $1^{+}$axons and protoglomeruli (Fig. $6 D$ ) are uncharacteristically present in the ventral OB. OCAM ${ }^{+}$axons, which normally extend into the ventral half of the rostral OB (Fig. $6 E$ ), are absent from the medial nerve layer in mutant mice (Fig. $6 F$ ). In addition, large $\mathrm{OCAM}^{+}$glomeruli are present in the 

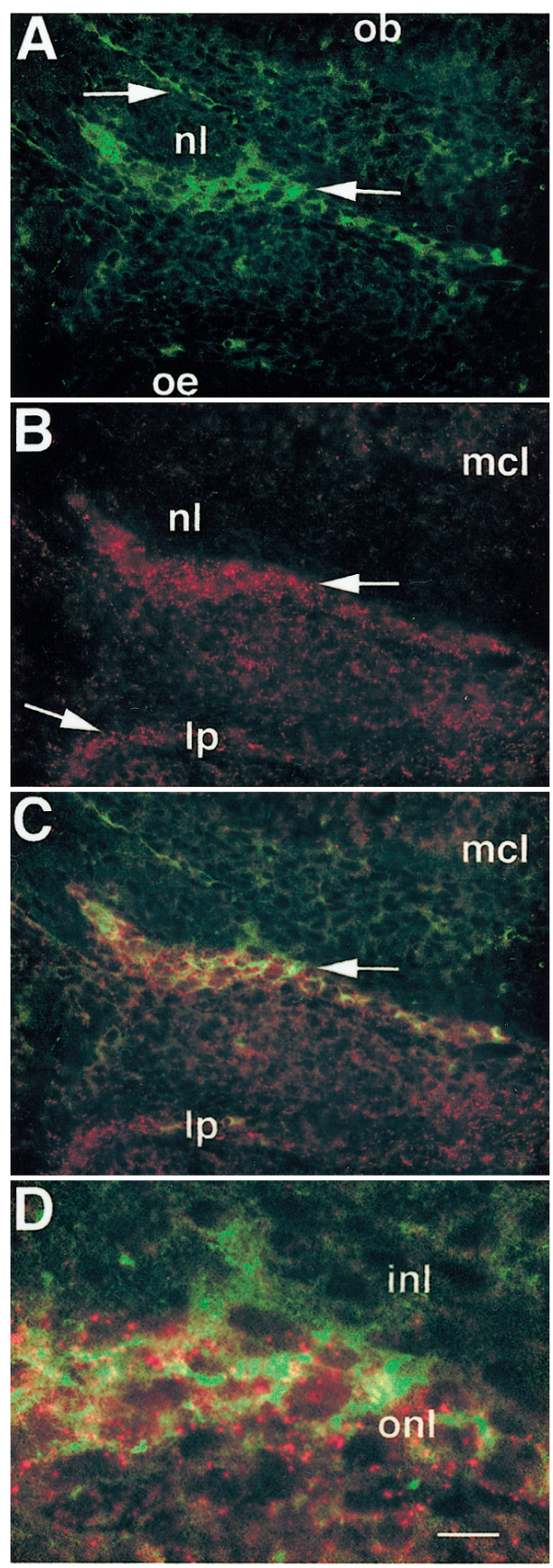

Figure 3. $\mathrm{P} 75^{+}$ensheathing cells express Sema3A. Immunofluorescence analysis of $\mathrm{p} 75(A)$ in a coronal section through the E15 mouse olfactory system reveals expression in the nerve layer ( $n l$, arrows) of the olfactory bulb $(o b)$. Fluorescence in situ hybridization analysis of the same section reveals Sema3A mRNA $(B)$ expression in the mitral cell layer $(\mathrm{mcl})$ of the $\mathrm{OB}$, the lamina propria, and the outer nerve layer (arrows). Double-label analysis (arrow in $C$ ) and a higher magnification image $(D)$ demonstrates that $\mathrm{p} 75^{+}$ensheathing cells in the outer nerve layer (onl) express Sema3A. p75 is also expressed to a lesser extent in the inner nerve layer (inl), but Sema3A is not. Dorsal is up, and medial is left. Scale bar: $A-C, 50 \mu \mathrm{m} ; D$, $15 \mu \mathrm{m}$.

ventral and medial nerve layers of wild-type mice (Fig. $6 E$ ) but are fewer in number and smaller in size in Sema3A mutant mice (Fig. $6 F$ ). Likewise, $\mathrm{LCG}^{+}$glomeruli, which are most abundant in the ventral half of the $\mathrm{OB}$, are numerous and distinct in wild-type mice at P0 (Fig. 6G) but poorly defined and less numerous, particularly in lateral regions in Sema3A mutant mice (Fig. $6 H$ ). These results suggest that, in addition to targeting errors by npn-1 $1^{+}$axons, some npn-1-negative sensory axons may also be aberrantly targeted in Sema3A mutant mice.
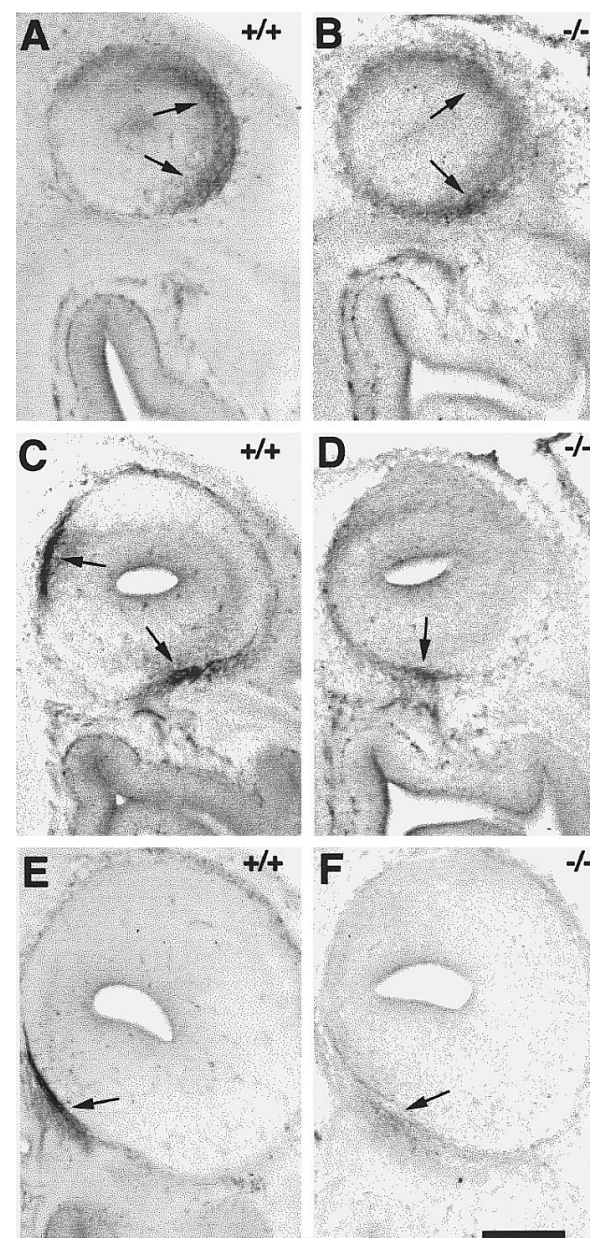

Figure 4. Npn- ${ }^{+}$axons are misrouted in Sema3 $\mathrm{A}^{-1-}$ mice. Matched coronal sections from the $\operatorname{rostral}(A, B)$, central $(C, D)$, or caudal $(E, F)$ OB of wild-type E13 $(+/+; A, C, D)$ or homozygous mutant Sema3A $(-/-; B$, $D, F)$ mouse embryos were reacted with anti-npn-1 antibodies. In homozygous mutant OBs $(B)$, npn- $1^{+}$axons (arrows) disperse into all regions of the rostral OB. In the central OB of mutant embryos, npn- $1^{+}$axons can only be found in the ventral nerve layer (arrow in $D$ ) in contrast to the npn- $1^{+}$axon fascicles in the medial and ventrolateral nerve layer of a matched section from wild-type mice (arrows in $C$ ). In the caudal OB from a Sema3A-1 mouse, only faint npn-1 ${ }^{+}$staining is visible in the ventral nerve layer (arrow in $F$ ) in contrast to the strongly stained npn- $1^{+}$axon bundle in the nerve layer of the medial OB of a matched section from a wild-type mouse $(E)$. Medial is left, and dorsal is up. Scale bar, $200 \mu \mathrm{m}$.

\section{DISCUSSION}

\section{Sema3A and npn-1 are expressed in complementary regions of the nerve layer}

There are $\sim 1000$ functionally distinct subsets of olfactory sensory neurons, each expressing only one odorant receptor gene. Neurons expressing a specific receptor extend axons that converge on a small number of glomeruli in the OB. The mechanism by which subsets of neurons project axons to these fixed targets is unknown. The expression patterns of class 3 semaphorins in chick and rodents make them attractive candidates for guiding olfactory sensory axons. Here, we show that, at least from E13 to P0, Sema3A plays a key role in the pattern of connections formed between the OE and OB. Figure 7 is a schematic representation of coronal sections through the developing olfactory system at three rostrocaudal levels. Sema3A mRNA (red) is distributed in a spiral pattern along the rostrocaudal axis that begins in the rostromedial $\mathrm{OB}$ and ends in the caudoventral OB. Npn- $1^{+}$axons (Fig. 7, blue) occupy a region complementary to Sema3A expression areas, growing into the lateral nerve layer rostrally and preferentially into the medial nerve layer caudally. In some areas, npn $-1^{+}$axons grow through narrow gaps in Sema3 $\mathrm{A}^{+}$cells, suggesting that the Sema3A protein does 

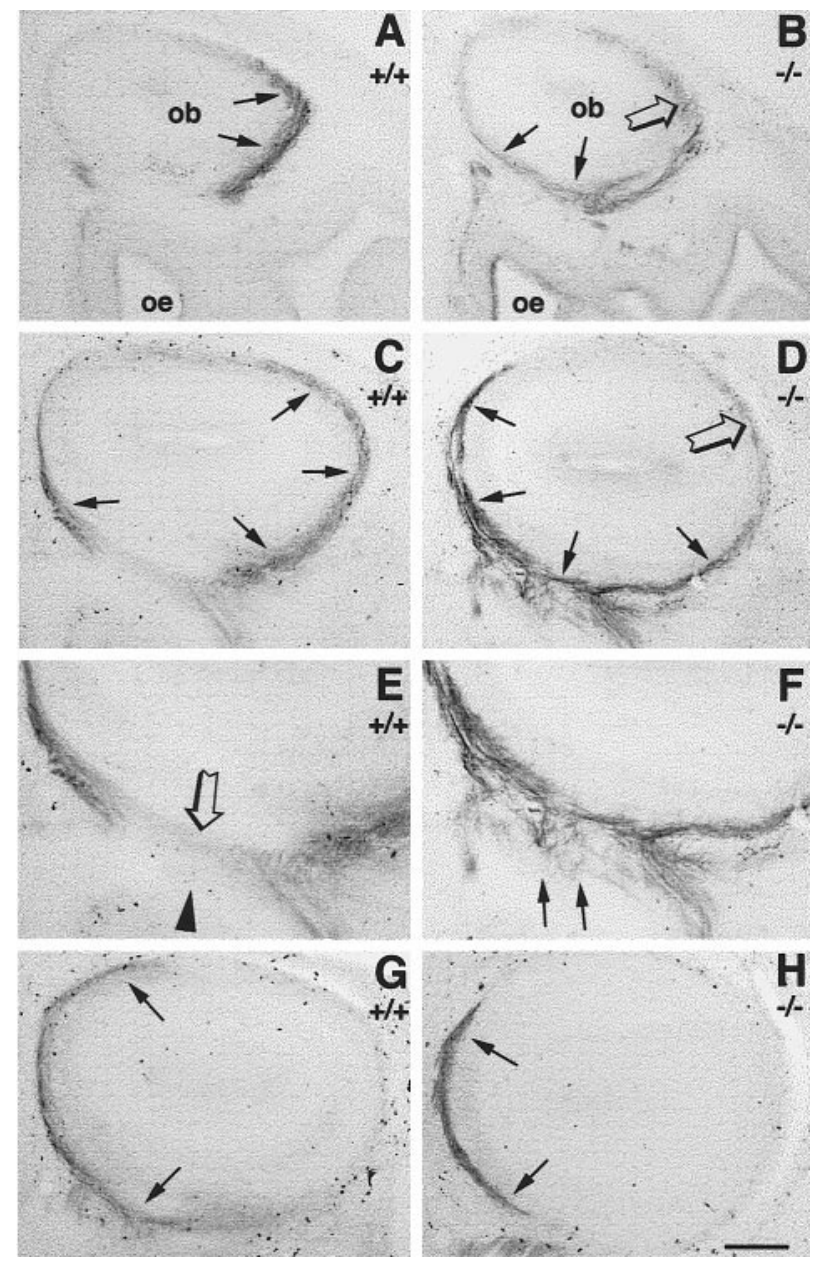

Figure 5. Npn-1 ${ }^{+}$axon trajectories are perturbed in Sema3A mutant mice. At E15, in the rostral OB, npn- $1^{+}$axons grow into the nerve layer of the lateral OB (arrows in $A$ ), as they do at E13. In a matched section (note the near identity in the size of the OBs and the shape of the OE turbinates) from Sema3A mutant mice, npn- $1^{+}$axons grow into the nerve layer in most areas of the OB (arrows in $B$ ). The intensity of staining in the lateral nerve layer (open arrow in $B$ ) is considerably lower than in the corresponding area from the matched wild-type section. In the central OB of wild-type mice, npn $-1^{+}$axons grow laterally and begin to form a medial component as they do in E13 animals (arrows in $C$ ). In a matched section (note the near identity in the size of the OBs and their ventricles) through the central OB of Sema3A mutant mice $(D)$, npn- $1^{+}$axons grow ventrally and medially (arrows in $D$ ), but the lateral axon bundle (open arrow) is significantly diminished compared with wild-type littermates. Higher magnification images of the ventral OBs from $C$ and $D$ demonstrate that a few npn- $1^{+}$fibers appear to grow through the inner nerve layer of the ventral OB (open arrow in $E)$, as the outer nerve layer is an area of high Sema3A expression (arrowhead in $E$ ). In Sema3A mutant mice, many npn- $1^{+}$axons grow directly through the outer nerve layer (arrows in $F$ ) of the ventral OB that is devoid of Sema3A. In the caudal OB, npn-1 $1^{+}$axons grow medially in wild-type mice $(G)$ and in mutants $(H)$. Medial is left, and dorsal is up. Scale bar: $A-D, G, H, 175 \mu \mathrm{m} ; E, F, 100 \mu \mathrm{m}$.

not diff use far from its source. In Sema3 $\mathrm{A}^{-/-}$mice, npn- $1^{+}$axons grow inappropriately into the medial nerve layer in the rostral and central $\mathrm{OB}$ and into the ventral nerve layer in all regions of the $\mathrm{OB}$, although axon trajectories in the caudal $\mathrm{OB}$ of mutants are relatively normal. The complementary pattern of expression of Sema3A and npn-1 suggests that these two molecules may contribute to a mechanism that divides the rodent $\mathrm{OB}$ into separate medial and lateral compartments. A common feature of odorant receptor-defined targeting is that each odorant receptor-specific axon subset converges on one lateral and one medial glomerulus and further that the lateral glomerulus is rostral relative to the position of the medial glomerulus (Zheng et al., 2000). This pattern is identical to the pattern of trajectories of npn- $1^{+}$axons, from E13 to birth, in which most lateral npn $-1^{+}$axons terminate in the rostral
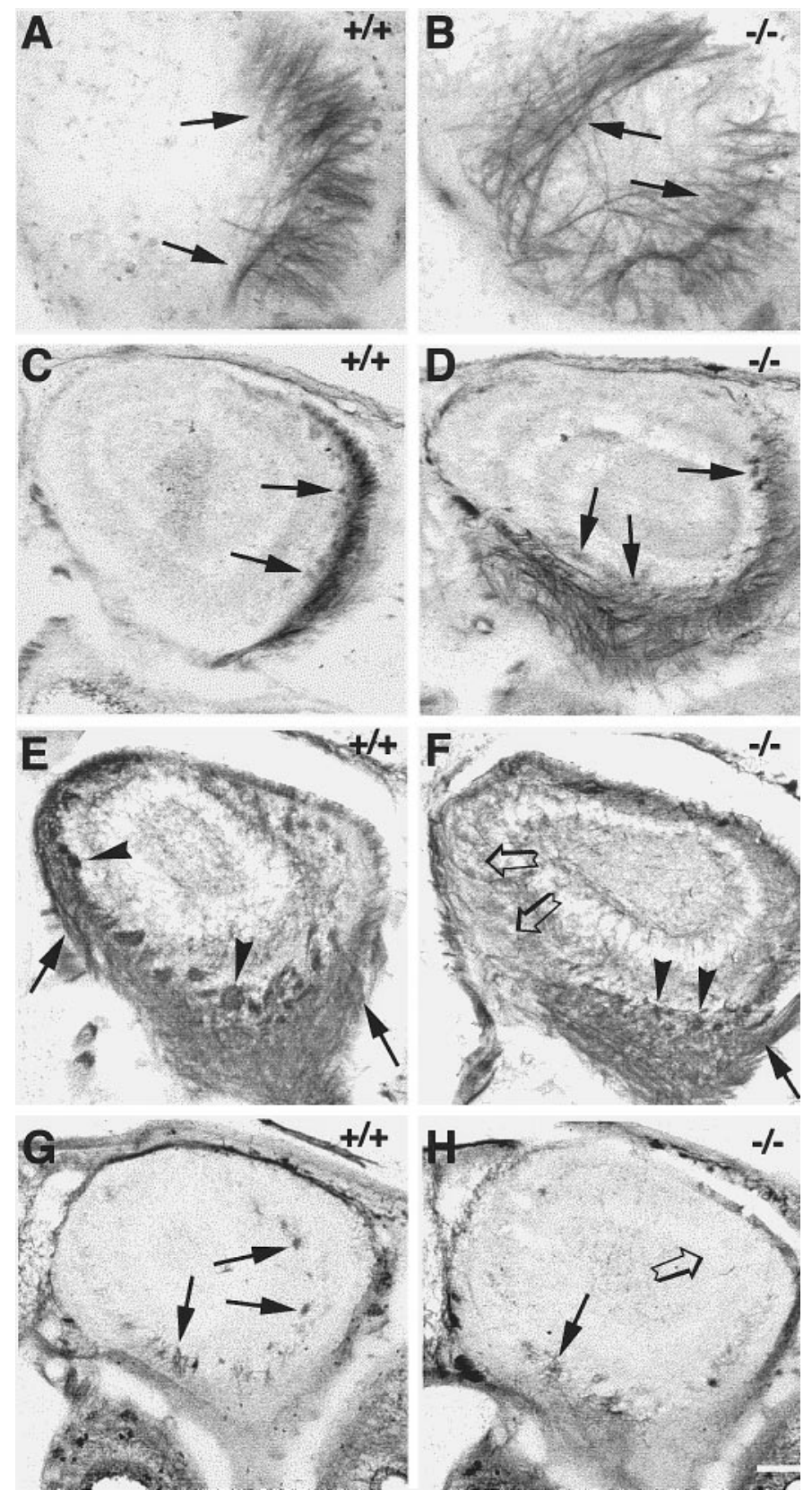

Figure 6. Glomerular targeting is aberrant in Sema3A $\mathrm{A}^{-1-}$ mice. The distribution of npn-1 ${ }^{+}(A-D), \mathrm{OCAM}^{+}(E, F)$, and $\mathrm{LCG}^{+}(G, H)$ axons was analyzed in sections of the rostral $\mathrm{OB}$ from $\mathrm{P} 0$ wild-type $(+/+; A, C, E$, $G)$ and Sema3A ${ }^{-1-}$ mice $(-/-; B, D, F, H)$. At the rostral tip of the OB, npn- $1^{+}$axons (arrows in $A$ ) extended laterally in wild-type OBs. However, npn-1 ${ }^{+}$axons were dispersed into the medial, ventral, and lateral nerve layer in Sema3 $\mathrm{A}^{-1-}$ mice $(B)$. Farther caudally in the OB, npn-1 ${ }^{+}$glomeruli in the lateral $\mathrm{OB}$ of wild-type mice are displaced into the ventral $\mathrm{OB}$ of Sema3A mutant mice (arrows in $C, D$ ). $\mathrm{OCAM}^{+}$axons (arrows in $E$ ) grow ventrally and medially in wild-type mice, but the medial axon tract is absent in Sema3A mutant mice (open arrows in $F$ ). In addition, the large $\mathrm{OCAM}^{+}$ protoglomeruli in medial and ventral areas of the OB in wild-type mice (arrowheads in $E$ ) are much less frequent and smaller in size in mutant mice $(F) . \mathrm{LCG}^{+}$glomeruli, which are small but distinct in the ventral and lateral $\mathrm{OB}$ at $\mathrm{P} 0$ in wild-type mice (arrows in $G$ ), are less numerous, particularly in the lateral OB (open arrow in $H$ ) of Sema3 $\mathrm{A}^{-/-}$mice and poorly defined in the ventral OB of mutants (arrow in $H$ ). Dorsal is up, and medial is left. Scale bar: $A, B, 50 \mu \mathrm{m} ; C-H, 100 \mu \mathrm{m}$.

OB and medial axons terminate in the caudal OB. Thus, odorant receptor expressing axons that are also npn- $1^{+}$will be restricted to rostrolateral and caudomedial compartments of the OB from the earliest stages of olfactory development.

The comparison of Sema3A ${ }^{+/+}$and Sema3 $\mathrm{A}^{-/-}$mice at differ- 

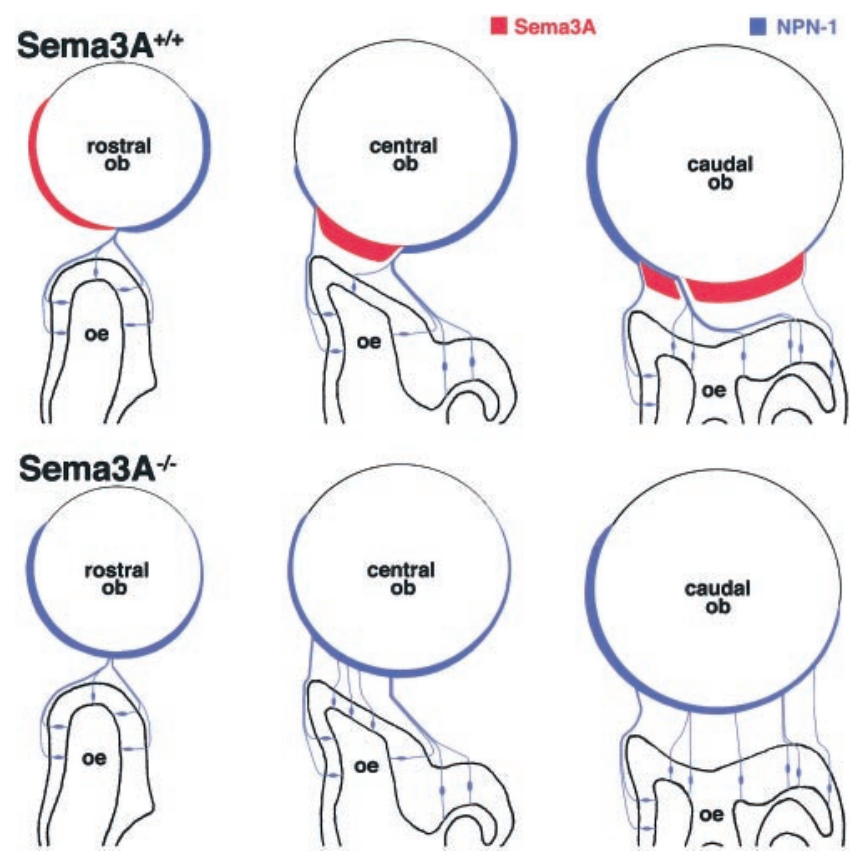

Figure 7. Sema3A guides npn-1 ${ }^{+}$axons in the olfactory bulb. A schematic illustration summarizes the distribution of Sema3A mRNA (red) and npn- $1^{+}$axons (blue) in the developing mouse olfactory system. In a series of coronal sections through the olfactory epithelium and bulb of wild-type mice, Sema3A can be seen in a spiral pattern along the rostrocaudal axis. In the rostral OB, Sema3A is expressed exclusively in the medial nerve layer but, in central and caudal sections Sema3A, expression moves to a ventral OB location. Axons expressing npn-1 are found in regions of the nerve layer complementary to Sema3A expression. They grow laterally in the rostral and central OB but extend mostly medially in the caudal OB, in some cases through gaps in the Sema3A expression pattern. In the absence of Sema3A, failure to repel axons from the ventral nerve layer allows npn- $1^{+}$axons to grow without restriction into either the medial and ventral nerve layers. Medial is left, lateral is right, and dorsal is up.

ent stages demonstrates the developmental progression of aberrant axon growth in the mutants. At E13, the total number of npn- $1^{+}$ axons is small and, although npn- $1^{+}$axons are clearly not normal in mutants at E13, it is not possible to determine whether aberrant trajectories result from fasciculation errors or guidance defects. However, by E15, significant errors in axon trajectories are visible in Sema3 $\mathrm{A}^{-1-}$ mice. Axons that normally grow only into the lateral $\mathrm{OB}$ are misdirected to the medial $\mathrm{OB}$. By $\mathrm{P} 0$, when glomeruli have begun to form, there are many npn- $1^{+}$glomeruli in Sema3 $\mathrm{A}^{-/-}$ mice in inappropriate positions, for example in the ventral OB. This suggests that aberrant axon trajectories seen in Sema3 $\mathrm{A}^{-1-}$ embryos leads to the formation of mistargeted termination sites in neonatal animals. We could not determine whether a correction of targeting mistakes occurs postnatally because mutant mice do not survive beyond P1.

\section{Sema3A repels $\mathrm{npn}-1^{+}$axons from the ventral nerve layer}

The role of Sema3A in regulating olfactory axon guidance in the mouse differs significantly from its function in chick (Kobayashi et al., 1997). Sema3A forms a barrier that prevents all sensory axons from entering the chick olfactory bulb for up to $2 \mathrm{~d}$ at the earliest stages of olfactory development, whereas in mouse, Sema3A selectively inhibits axons from entering the ventral $\mathrm{OB}$ throughout development. In rodents, Sema3A is expressed by mitral and tufted cells in the embryonic OB and by non-neuronal cells in the developing nasal compartment but not in sensory neurons (Giger et al., 1996). It was suggested that Sema3A might play a role in the rodent OB similar to that in the chick. Although npn- $1^{+}$axons terminate in restricted regions of the $\mathrm{OB}$ in adult rats (Pasterkamp et al., 1998), there has been little direct evidence that Sema3A alone plays an important role in guidance of sensory neurons. Indeed, the phenotype described here would not be predicted based on the overall pattern of Sema3A expression in this system. However, analysis of Sema3 $\mathrm{A}^{-1-}$ mice here confirms that npn- ${ }^{+}$axons grow from the OE into the OB in the absence of Sema3A in the nasal mesenchyme and lamina propria. It also appears that npn- $1^{+}$axons will not overgrow their targets in the OB in the absence of Sema3A in mitral or tufted cells or in the cranial mesenchyme. However, loss of Sema3A expression in the nerve layer of the OB, a choice point for axons making final targeting decisions, alters the trajectories of many axons entering the ventral nerve layer.

Analysis of axon trajectories in mice lacking Sema3A (Taniguchi et al., 1997) has revealed extensive defasciculation of peripheral sensory nerves but few axon guidance errors in the CNS (Behar et al., 1996; Catalano et al., 1998; Ulupinar et al., 1999). Similarly, the major defect seen in neuropilin-1 and -2 mutant mice is defasciculation of peripheral nerves (Kitsukawa et al., 1997; Chen et al., 2000; Giger et al., 2000). Specific axon tracts are also missing in neuropilin-2 mutants (Giger et al., 2000; Chen et al., 2000). In contrast, Polleux et al. (1998, 2000) have clearly demonstrated aberrant orientation of axons and dendrites of cortical pyramidal cells in Sema3 $\mathrm{A}^{-1-}$ mice and that endogenous Sema3A acts as a chemoattractant to direct growth of cortical dendrites. Here, we report the first severe axon guidance perturbations in the CNS of mice lacking Sema3A and show that the repulsive activity of Sema3A is important for guidance, not just fasciculation, of olfactory axons. The observation of ectopic npn- $1^{+}$protoglomeruli in Sema3A $\mathrm{A}^{-1-}$ mice is reminiscent of the phenotype of Drosophila Sema2a loss-of-function mutants, which show ectopic synaptic contacts with embryonic body wall muscles (Winberg et al., 1998). Thus, the regulation of target innervation might represent an evolutionarily conserved function of secreted semaphorins.

Patterning in the olfactory system is characterized by the convergence of axons expressing one of $\sim 1000$ distinct odorant receptor genes from broad regions of the $\mathrm{OE}$ to a small number of glomeruli in the OB (Ressler et al., 1993; Bulfone et al., 1998; Wang et al., 1998). Odorant receptors play an instructive role in this process (Mombaerts et al., 1996; Lin and Ngai, 1999), but only a few nonreceptor molecules known to be expressed during development would appear to fit the criterion for guidance factors in this system (for review, see Lin and Ngai, 1999). One is OCAM, an Ig-family member that is expressed in a pattern consistent with the receptor defined zones. Another is LCG, a marker for spatially restricted axon subsets terminating in the ventromedial OB (Mahanthappa et al., 1994). LCG-mediated interactions with galectin-1 may play a role in guidance (Puche et al., 1996) or may create permissive substrates in the ventral OB (Crandall, Dibble, Butler, Pays, Ahmed, Kostek, and Püschel, unpublished observations). A majority of $\mathrm{LCG}^{+}$axons and many $\mathrm{OCAM}^{+}$axons terminate in the ventral OB. These axons do not express npn-1 and are capable of growing directly through the Sema3A-enriched ventral nerve layer. We have shown previously that the ventral nerve layer expresses laminin and galectin-1 (Raabe et al., 1997), substrates that are apparently conducive to $\mathrm{OCAM}^{+}$and $\mathrm{LCG}^{+}$axon growth.

Interestingly, the patterns of growth of $\mathrm{OCAM}^{+}$and $\mathrm{LCG}^{+}$ axons are also perturbed in Sema3A ${ }^{-1-}$ mice. There are several possible explanations for this finding. One, some npn- $1^{+}$axons probably express OCAM or LCG, and loss of Sema3A may affect the trajectories of double-labeled axons. Two, the loss of Sema3A from the ventral nerve layer may create a situation in which npn- $1^{+}$ axons compete for limiting amounts of permissive factors normally reserved for $\mathrm{LCG}^{+}$or $\mathrm{OCAM}^{+}$axons, similar to a model proposed for ephrin function in retinocollicular mapping (Feldheim et al., 2000). For example, OCAM ${ }^{+}$axons normally extend through the ventral nerve layer to targets in the ventromedial OB. In Sema $3 \mathrm{~A}^{-1-}$ mice, fewer $\mathrm{OCAM}^{+}$axons project to the ventromedial nerve layer, perhaps because this region is highly populated with aberrant npn- $1^{+}$axons.

In summary, the results reported here present the first report of severe axon guidance perturbations in the CNS of mice lacking 
Sema3A and show that the repulsive activity of Sema3A is important not only for the fasciculation of sensory axons but also for the guidance of olfactory axons. Sema3A contributes to patterning of connections formed between the $\mathrm{OE}$ and $\mathrm{OB}$ by providing a guidance signal for a subset of these axons, the npn- $1^{+}$axons, that restricts them to a defined region of the OB. Sema3A is the first nonodorant receptor molecule shown to play a role in the convergence and divergence of olfactory axons. Thus, ensheathing cells in the nerve layer of the OB differentially express molecules capable of regulating trajectories of axon subsets.

\section{REFERENCES}

Behar O, Golden JA, Mashimo H, Schoen FJ, Fishman MC (1996) Semaphorin III is needed for normal patterning and growth of nerves, bones and heart. Nature 383:525-528.

Bulfone A, Wang F, Hevner R, Anderson S, Cutforth T, Chen S, Meneses J, Pedersen R, Axel R, Rubenstein JL (1998) An olfactory sensory map develops in the absence of normal projection neurons or GABAergic interneurons. Neuron 21:1273-1282.

Catalano SM, Messersmith EK, Goodman CS, Shatz CJ, Chedotal A (1998) Many major CNS axon projections develop normally in the absence of Semaphorin III. Mol Cell Neurosci 11:173-182.

Chen H, Bagri A, Zupicich JA, Z ou Y, Stoeckli E, Pleasure SJ, Lowenstein DH, Skarnes WC, Chedotal A, Skarnes WC, Tessier-Lavigne M (2000) Neuropilin-2 regulates the development of selective cranial and sensory nerves and hippocampal mossy fiber projections. Neuron 25:43-56.

Feldheim DA, Kim YI, Bergemann AD, Frisen J, Barbacid M, Flanagan JG (2000) Genetic analysis of ephrin-A2 and ephrin-A5 shows their requirement in multiple aspects of retinocollicular mapping. Neuron 25:563-574.

Giger RJ, Wolfer DP, DeWit MJ, Verhaagen J (1996) Anatomy of rat semaphorin III/collapsin-1 mRNA expression and relationship to developing nerve tracts during neuroembryogenesis. J Comp Neurol 375:378-392.

Giger RJ, Cloutier JF, Sahay A, Prinjha RK, Levengood DV, Moore SE, Pickering S, Simmons D, Rastan S, Walsh FS, Kolodkin AL, Ginty DD, Geppert M (2000) Neuropilin-2 is required in vivo for selective axon guidance responses to secreted semaphorins Neuron 25:29-41.

Gong Q, Shipley MT (1996) Expression of extracellular matrix molecules and cell surface molecules in the olfactory nerve pathway during early development. J Comp Neurol 366:1-14.

Kafitz KW, Greer CA (1998) Differential expression of extracellular matrix and cell adhesion molecules in the olfactory nerve and glomerular layers of adult rats. J Neurobiol 34:271-282.

Kawakami A, Kitsukawa T, Takagi S, Fujisawa H (1995) Developmentally regulated expression of a cell surface protein, neuropilin, in the mouse nervous system. J Neurobiol 29:1-17.

Kitsukawa T, Shimizu M, Sanbo M, Hirata T, Taniguchi M, Bekku Y, Yagi T, Fujisawa H (1997) Neuropilin-Semaphorin III/D-mediated chemorepulsion signals play a crucial role in peripheral nerve projection in mice. Neuron 19:995-1005.

Kobayashi H, Koppel AM, Luo Y, Raper JA (1997) A role for collapsin-1 in olfactory and cranial sensory axon guidance. J Neurosci 17:8339-8352.

Kolodkin AL, Levengood DV, Rowe EG, Tai Y-T, Giger RJ, Ginty DD (1997) Neuropilin is a semaphorin III receptor. Cell 90:753-762.

Lin DM, Ngai J (1999) Development of the main olfactory system. Curr Opin Neurobiol 9:74-78.

Luo Y, Raible D, Raper JA (1993) Collapsin: a protein in brain that induces the collapse and paralysis of neuronal growth cones. Cell 75:217-227.

Mahanthappa NK, Cooper DNW, Barondes SH, Schwarting GA (1994) Rat olfactory neurons can utilize the endogenous lectin, L-14, in a novel adhesion mechanism. Development 120:1373-1384.
Mombaerts P, Wang F, Dulac C, Chao SK, Nemes A, Mendelsohn M, Edmondson J, Axel R (1996) Visualizing an olfactory sensory map. Cell 87:675-686.

Mori K, Nagao H, Yoshihara Y (1999) The olfactory bulb: coding and processing of odor molecule information. Science 286:711-715.

Pasterkamp RJ, DeWinter F, Holtmaat AJGD, Verhaagen J (1998) Evidence for a role of the chemorepellent semaphorin III and its receptor neuropilin-1 in the regeneration of primary olfactory axons. J Neurosci 18:99c2-9976.

Polleux F, Giger RJ, Ginty DD, Kolodkin AL, Ghosh A (1998) Patterning of cortical efferent projections by semaphorin-neuropilin interactions. Science 282:1904-1906.

Polleux F, Morrow T, Ghosh A (2000) Semaphorin 3A is a chemoattractant for cortical apical dendrites. Nature 404:567-573.

Puche AC, Poirier F, Hair M, Bartlett PF, Key B (1996) Role of galectin-1 in the developing mouse olfactory system. Dev Biol 179:274-287.

Püschel AW, Adams RH, Betz H (1995) Murine semaphorin D/collapsin is a member of a diverse gene family and creates domains inhibitory for axonal extension. Neuron 14:941-948.

Raabe EH, Yoshida K, Schwarting GA (1997) Differential laminin isoform expression in the developing rat olfactory system. Dev Brain Res 101:187-196.

Ressler KJ, Sullivan SL, Buck LB (1993) A zonal organization of odorant receptor gene expression in the olfactory epithelium. Cell 73:597-609.

Rohm B, Ottemeyer A, Lohrum L, Püschel AW (2000) Plexin/neuropilin complexes mediate repulsion by the axonal guidance signal semaphorin 3A. Mech Dev 93:95-104.

Schwarting GA, Crandall JE (1991) Subsets of olfactory vomeronasal sensory epithelial cells and axons revealed by monoclonal antibodies to carbohydrate antigens. Brain Res 547:239-248.

St. John JA, Key B (1999) Expression of galectin-1 in the olfactory nerve pathway of rat. Brain Res Dev Brain Res 18:171-178.

Takahashi T, Fournier A, Nakamura F, Wang L-H, Murakami Y, Kalb RG, Fujisawa H, Strittmatter SM (1999) Plexin-Neuropilin-1 complexes form functional semaphorin-3A receptors. Cell 99:59-69.

Tamagnone L, Artigiani S, Chen H, He Z, Ming GI, Song H, Chedotal A, Winberg ML, Goodman CS, Poo M, Tessier-Lavigne M, Comoglio PM (1999) Plexins are a large family of receptors for transmembrane, secreted, and GPI-anchored semaphorins in vertebrates. Cell 99:71-80.

Taniguchi M, Yuasa S, Fujisawa H, Naruse I, Saga S, Mishina M, Yagi T (1997) Disruption of semaphorin III/D gene causes severe abnormality in peripheral nerve projection. Neuron 19:519-530.

Ulupinar E, Datwani A, Behar O, Fujisawa H, Erzurumlu R (1999) Role of semaphorin III in the developing rodent trigeminal system. Mol Cell Neurosci 13:281-292.

Wang F, Nemes A, Mendelsohn M, Axel R (1998) Odorant receptors govern the formation of a precise topographic map. Cell 93:47-60.

Wanner I, Baader SL, Brich M, Oberdick J, Schilling K (1997) Subcellular localization of specific mRNAs and their protein products in Purkinje cells by combined fluorescence in situ hybridization and immunocytochemistry. Histochem Cell Biol 108:345-357.

Winberg ML, Mitchell KJ, Goodman CS (1998) Genetic analysis of the mechanisms controlling target selection: complementary and combinatorial functions of netrins, semaphorins, and IgCAMs. Cell 93:581-591.

Yoshihara Y, Kawasaki M, Tamada A, Fujita H, Hayashi H, Kagamiyama H, Mori K (1997) OCAM: a new member of the neural cell adhesion molecule family related to zone-to-zone projection of olfactory and vomeronasal axons. J Neurosci 17:5830-5842.

Young WWJ, Portoukalien J, Hakomori SI (1981) Two monoclonal anticarbohydrate antibodies directed to glycosphingolipids with a lacto- $N$ glycosyl type II chain. J Biol Chem 256:10967-10977.

Zheng C, Feinstein P, Bozza T, Rodriguez I, Mombaerts P (2000) Peripheral olfactory projections are differentially affected in mice deficient in a cyclic nucleotide-gated channel subunit. Neuron 26:81-91. 